\title{
Becoming Social Museums by Being Virtual-Oriented and Technology-Driven Organisations
}

\section{Mauro ROMANELLI}

Parthenope University of Naples, Department of Business and Economics; 13 Via G. Parisi, 80132

Napoli, Italy; (iD mauro.romanelli@uniparthenope.it

\begin{abstract}
As audience-oriented and information-driven organisations, museums are embracing the Internet and interactive technology for developing virtual museums by encouraging the participation of the users in cultural activities. Technology does not exist per se being socially shaped. Museums have the opportunity to promote social innovation by developing technology and opening up to the audience as an active participant in the definition of cultural contents emphasising the interaction and communication between museums and their users. The Internet and interactive technology help museums to drive service innovation by opening up to the participation of the audience in defining cultural heritage contents. As virtual-oriented and technology-driven organisations, museums are becoming social, developing social spaces for innovation, selecting different pathways by managing information and knowledge sharing, developing interactive and virtual technology, building a shared authority on cultural heritage, involving the user as an active participant in co-production of cultural heritage knowledge.
\end{abstract}

Keywords: museums; information technology; virtual museums; virtual heritage; cultural heritage; user participation.

\section{Introduction}

Museums are using the technology to generate new knowledge to their audience and promote new cultural experiences, developing interactive communication with the public, by involving a wide community of potential visitors who are likely to take part in the definition and production of cultural content.

Museums are non-profit making permanent institutions in the service of society and of its development, and open to the public, which acquire, conserve, research, communicate and exhibit, for purpose of study, education, and enjoyment, material evidence of people and their environment according to the ICOM Statutes, adopted during the $21^{\text {st }}$ General Conference in Wien (2007). The museum is an evolving and dynamic institution and organisation. Hooper-Greenhill (2007) has identified some key elements of the postmodern museum: "a more sophisticated understanding of the complex relationships between culture, communication, learning and identity that will support a new approach to museum audiences; a second basic element is the promotion of a more egalitarian and just society; and linked to these is an acceptance that culture works to represent, reproduce and constitute self-identities and that this entails a sense of social and ethical responsibility" (p. 1). Vicente, Camarero, and Garrido (2012) have defined innovation "as a tendency to incorporate new systems, technologies or processes that change both how the museum is run and how its exhibits are presented to the visitor" (p. 652). Innovation acts as a mediator between market orientation and the social performance of museums (Camarero \& Garrido, 2008).

Technology opens up innovation in processes, behaviours, and organisation. Museums shape technology by designing a virtual museum and promoting social innovation and value for the community, taking into account the perspective of different users interacting between them (Russo \& Watkins, 2008), fostering cultural participation and engagement (Niccolucci, 2007). The use of technology is leading museums to creating a visitor-friendly environment, focusing on communication and emotional involvement of

How to cite

Romanelli, M. (2021). Becoming Social Museums by Being Virtual-Oriented and Technology-Driven Organisations. Culture. Society. Economy. Politics. 1(1), 79-92. DOI 10.2478/csep-2021-0006 ISSN (online) 2810-2010 
visitors (Gilmore \& Rentschler, 2002) who actively participate and determine their own experience (Roussou, 2002).

Web 2.0 technologies help to make cultural production more democratic, driving users to generate and share their museum content (Shahani, Economou, \& Nikomanou, 2008). Virtual exhibitions contribute to enhancing the experience of visitors and attracting a new audience (Charitos et al., 2001). Information and communication technologies (ICTs), digital innovation, and virtual environments help to enhance the potential of museums as suppliers of cultural consumption goods and significantly enable the museum to develop the ability to attract new visitors and improve visitors' experiences, satisfaction, and loyalty (Mancini \& Carreras, 2010; Zollo, Rialti, Marrucci, \& Ciappei, 2021). Digital technology facilitates that museums' educative missions are enhanced through cultural experiences (Pruulman-Vengerfeldt \& Aljas, 2009). Technology enables social action and learning (Hein, 2005). Museums are becoming repositories of heritage and spaces of cultural innovation, as meeting places and contact zones for meaning construction and dialogue (Srinivasan, Becvar, Boast, \& Enote, 2011).

As cultural connectors (Castells, 2001), museums rediscover the intangible aspects of the museum experience (Alcaraz, Hume, \& Mort, 2009), promoting opportunities for learning, education, and participation (Lòpez, Margapoti, Maragliano, \& Bove, 2012) by using technology. The traditional role and mission of museums may support the enhancement of innovation (Delle Nogare \& Murzyn-Kupisz, 2021). Today, the role of museums is reinvented by valuing the potential of the Internet, virtual and interactive technologies applied to the interaction between objects, information, users, museum communities actively cooperating for engendering new knowledge as an immediate result and issue of the value co-creation process. Museums contribute to building social capital (Burton \& Scott, 2007; Murzy-Kupisz, 2013), developing a sense of identity within the community, and generating income and economic benefits (Scott, 2003), by developing new interactive technology and virtual environments.

Technology is enabling museums as institutions mass communication oriented (HooperGreenhill, 1995) to adapt to a changing society (Bautista, 2014), driving the visitors from being only a recipient and beneficiary to becoming an informant and producer providing input and acting as creator (Scott, 2010), and giving staff and communities the opportunity for collaboration and networks (Kelly, 2010). It is recognized the role of a visitor as bringing a living reality to the museum experience being connected to the museum space and its information-carrying function (Vergo, 1989; Hooper-Greenhill, 1992).

Technologies offer museums new opportunities for managing communication and knowledge transmission, engaging the audience for cultural interactive experiences' creation (Russo, 2011), employing the input of the public as a central contribution (Arnold \& Geser, 2007), and developing a new application for user-generated content and creation of web-based communication in cultural heritage (Silberman, 2007). As cultural organisations, museums pay attention to how ICTs applications exert influence on the experience of the exhibition in terms of visitors' behaviour, the social dimension of the visit, and the integration with other exhibits (Economou \& Pujol, 2008).

Museums contribute to sustainable development, improving the quality of life, and promoting the social and cultural growth of communities (Pop \& Borza, 2014). Having this in mind, to increase their impact on their communities, museums develop complex strategies of stakeholder management (Zbuchea \& Bira, 2020). As responsive organisations, museums are sustaining participatory engagement and involving participants in museum experience (Simon, 2010).

The present research implies investigating how museums are using technology to make the museum a social institution by and beyond the virtual museum. The study aims to explain that museums select different pathways, following an information or knowledge 
orientation, by managing collections or involving the audience to participate for a definition of contents by shaping technology.

Technology helps museums to design the virtual museum as a digital projection of traditional museums or open the possibility for museums as a community for promoting social value and innovation, involving the users in the production of cultural content. This study refers to an analysis and literature review about the concept of virtual museums and the use of Internet technologies of information and communication to develop interactive communication between the museum and the public.

This study aims mainly to provide an interpretive and qualitative framework. The research is considering the literature related to the role of the Internet, virtual and interactive technologies as a means that enables museums to contribute to innovation for creating social and cultural value by opening up to increasing user involvement and participation in the definition of cultural heritage contents. The analysis elucidates how museums are supporting the idea of a social museum which strengthens user participation as social innovation by using the potential offered by information and digital technology as applied in the cultural heritage field. Referred journal articles were selected from Google scholar as the main web source and database. The selected contributions are summarized and interpreted (Denyer \& Tranfield, 2006) in a narrative synthesis that accommodates differences between the questions, research design, and the context of the studies considered to develop new perspectives on emerging issues and advance theoretical models (Dixon-Woods, Agarwal, Young, Jones, \& Sutton, 2004).

The study is articulated in the following way. After the Introduction, in the second section, virtual heritage for valuing cultural heritage is presented. In the third and fourth parts, museums are investigated both as social institutions promoting innovation by shaping technology and information and knowledge-driven organisations. In the fifth section, the role of the virtual museum is elucidated. In the sixth section, the use of information technology helps to construct a 'shared' authority on cultural heritage between the museum and the public. Finally, discussion and conclusions are set out.

\section{Virtual heritage for valuing cultural heritage}

According to the Council of Europe (2005), cultural heritage is considered to be a group of resources inherited from the past which people identify, independently of ownership, as a reflection and expression of their constantly evolving value, beliefs, knowledge, and traditions. It includes all aspects of the environment resulting from the interaction between people and place through time. The concept of cultural heritage is dynamic (Vecco, 2010), evolving from considering monuments, objects, and preservation to paying attention to people and functions, valuing sustainable use and development (Loulansky, 2006).

Valorising heritage refers to the activities to promote the knowledge of cultural heritage to guarantee the best conditions for public use and fruition. Cultural heritage is becoming an important application for employing virtual reality technology. Virtual heritage refers to the use of computer-based interactive technology to record, preserve, or recreate artefacts, sites, and actors of historic, artistic, religious, and cultural significance and to deliver the results openly to a global audience and provide formative educational experiences through electronic manipulations of time and space (Stone \& Ojika, 2000).

Virtual reality applications and digital techniques open up new opportunities for managing and appreciating the content and meaning of cultural goods (Addison, 2000), involving the audience and providing an effective learning environment (Tost \& Champion, 2007). Virtual heritage applications help to enhance the use of the immersive and interactive virtual reality and give museum visitors access to computer reconstructions of historical normally sites inaccessible, and offer museums a new 
opportunity to support educational aims, bringing together cultural and public awareness and entertainment, and the acceptance of technology (Roussou, 2002; 2008).

Virtual environment technology increasingly helps both for conservation and documentation by enhancing divulgation and education, stimulating interaction between users and environments. Virtual environments allow or compel the user to have a sense of being present in an environment other than the one they are actually in, and to interact with it (Schroeder, 2008). Virtual environments relate to the physical environment in three types: replacement, complement, or independence. The virtual space can be identical to the physical space or can act as a complementary function. The virtual space as independent of physical space can create new experiences that differ from the existing ones (Chiu, Lin, Tseng, \& Chen, 2000).

\section{Museums becoming social by shaping technology}

Museums provide both social and educational roles serving different kinds of public (DiMaggio, d'Harnoncourt, Perry, \& Wood, 1991). Museums promote social innovation by shaping new digital technology to enhance cultural experiences, reducing the gap between museums and people, and preserving the past for future knowledge (PruulmanVengerfeldt \& Aljias, 2009). ICT enables museums to support educational purposes (Ott \& Pozzi, 2011). Technology does not exist per se. It is socially constructed. Technological innovation and multimedia installations provide portholes through which the museum collection is viewed (Bearman \& Gebra, 2008), enabling an emotional space and empowering the museum visitor for a re-reading of objects (Witcomb, 2007).

Thereby, technology is socially shaped and does not automatically determine social structures and relationships. Innovation is a contradictory and uncertain process not driven by rationality and determined by technique dictates. Technology is a social product. Technological change is conceived as a social process influenced by social and economic factors and aspects (Williams \& Edge, 1996). Thereby, people are not passive actors in front of the technology but they are likely to reject or redefine technology in a way that defies its original and designed purpose (Mackay \& Gillespie, 1992).

Computer-based as mind-technology supports the cognitive processes of human beings. Thereby, technology offers solutions for museums promoting culture by transmitting knowledge (Antinucci, 1998) and utilising multimedia, visual and virtual reality to communicate cultural contents and involve the users in the cultural contents' definition (Carrozzino \& Bergamasco, 2010).

As cultural organisations dealing with digital communication, museums provide cocreative infrastructure for the community and distribute cultural content to the audience in order to support community representation (Russo \& Watkins, 2007). Museums use multimedia applications for communicating a message through the presentation or interpretation of objects by taking into account both technical and aesthetic-pedagogical implications (Economou, 1998). Digital objects have an active use in promoting meaning and dialogue for museums as meeting places and contact zones for expert communities engaging with objects (Srinivasan, Becvar, Boast, \& Enote, 2010). As a community, museums attribute meanings and messages to the use of technology to reproduce cultural contents, as increased accessibility and to contribute to study and research, developing a communication system able to relate to the public (Antinucci, 1998).

Museums use technology in order to serve the educational mandate (Anderson, 1999), to support a positive image of the museum as a knowledge and learning-oriented organisation (Hazan, 2007), by engaging with the public, building a new legitimacy of a social and public value-driven museum (Holden, 2006). As mass communicationoriented organisations through exhibitions (Hooper-Greenhill, 1995), museums are using technology to better provide a civilising influence on the society and legitimise the educative mission in front of the stakeholders (Keene, 1997). In the information era, 
museums become cultural connectors, spaces of innovation and experimentation by using information technology to involve the public and making the collections more accessible to the public (Castells, 2001), developing social innovation by meeting a social need (Mulgan, 2006).

\section{Museums as information and knowledge-oriented organisations}

As organisations (Bagdadli, 1997), cultural and memory institutions, and symbols of a community (Burton \& Scott, 2007), museums contribute to social value and serve society by providing new knowledge to their audience, collecting, preserving, researching, and displaying cultural heritage by connecting past with present and future. Museums perform at least four functions (Davies, Paton, \& O'Sullivan, 2013): preserve by collecting and conserving the collection; understand by studying and researching the material; communicate by the presentation and interpretation of collections; contribute to civil society by building a national identity and belonging of individuals to the cultural community. Museums are opening up to flexible and multiple interpretations of knowledge and understanding, where meanings are constantly rediscovered, involving the audience or visitors, the community outside as stakeholders, shaping the museum as a forum mode which encourages the debate and actively contributes to civic society, becoming a shared depository, and involving visitors in creating meaning from the collections (Davies, Paton, \& O'Sullivan, 2013).

Museums are information-intensive organisations and storehouses of knowledge (Bagdadli, 1997; Freedman, 2000; Marty, 2007; MacDonald \& Alsford, 1991), managing communication and dissemination of knowledge (Schweibenz, 1998; Schweibenz, 2011). Museums are concerned with the generation, the perpetuation, the organisation, and the dissemination of information, and actively use the information to create understanding or help their audience to exploit effectively the information resources for knowledge (MacDonald \& Alsford, 1991).

As information-intensive organisations (Marty, 2011), museums shape knowledge. The information is embedded both in the organisational memory and its collections and documented information resources (Huvila, 2013). As a community of stakeholders, the museum uses the information as what can be communicated to people and knowledge as the result of the interaction, of experience organised and stored in the mind of the individuals (Orna \& Pettitt, 2010). Today, as agents of cultural change and knowledge municipalities museums legitimise the processes of capture, management, and dissemination of information and knowledge (Freedman, 2000).

\section{Virtual museums: strengthening the technology for information and knowledge access}

Technology computer-based and informatics add a digital dimension to the physical dimension of a museum by building a virtual museum as an interactive virtual space for information provision and exhibition of cultural objects in digital format.

The idea of a museum as an entity conceived without barriers of space and time is generated for the first time in the study of Malraux Le Musee Imaginaire (1947) as a necessary premise to the work of Tsichritzis and Gibbs (1991) that have used the term 'virtual museum' for the first time. The 'virtual museum' is defined as a logically related collection of digital objects composed in a variety of media, and, because of its capacity to provide connectedness and various points of access, it lends itself to transcending traditional methods of communicating and interacting with the visitors being flexible toward their needs and interests; it has no real place or space, its objects and the related information can be disseminated all over the world (Schweibenz, 1998; Schweibenz, 2011). 
Museums focus attention and resources on information rather than objects and artefacts as a storehouse of knowledge (Schweibenz, 2011). The strength and authenticity of the virtual museum as a source of information are centered on information mainly available on the Internet rather than physical objects (Schweibenz, 1998). The virtual museum is not the physical museum transposed to the web, enabling visitors to 'see' collections without going to a physical museum. The strength and the authenticity of the virtual museum rely on the communicative projection of the traditional and physical museum, by developing visual-interactive technology to enhance the appreciation of collections by a greater public of visitors and wide audience (Antinucci, 2007).

Different practices and modes of representation emerge: in a narrative-centered mode the cultural objects are presented to support evidence to the storyline; in the objectcentered mode the integrity of artefacts and the intrinsic value of objects is carefully maintained; the information-centered mode best fits in the information transmission model (Tang, 2005). While in the physical environment only a limited amount of information about the cultural artefacts is available, in virtual museum exhibitions and artefacts are digitized and visualized into a virtual interactive environment. The cultural information is preserved and disseminated in a low-cost way. The virtual museum seems to appear as digital reflections acting as a complementary entity and extension of the physical museum (Styliani, Fotis, Kostas, \& Petros, 2009).

Virtual museum as a complement to traditional museums may promote inclusion and diversity through experiences that benefit visitors and users. In an interactive museum, all data stored through a database are shown in the website obtaining information through queries in the database by simply clicking on them (Robles Ortega, Feito, Jiménez, \& Segura, 2012).

Three categories of virtual museums are identified. The brochure museum is a website that informs future visitors containing administrative information about the museum, such as opening hours, services, types of collections, floor plan of the museum, map of the area where it is situated, contact details, etc. The content museum as a website makes available information about the museum collections. The content is presented in an object-oriented way. The learning museum is a website that establishes a personal relationship between the virtual visitor and the museum, by offering different points of access to the virtual visitors (age, background, knowledge).

The information is presented in a way context-oriented rather than object-oriented, driving the virtual visitor to learn more about a subject of particular interest to them and to visit the site again (Styliani, Fotis, Kostas, \& Petros, 2009). Virtual museums emerging as an engaging medium for visitors by promoting the physical site provide information about exhibitions, preserve and disseminate effectively and by a low-cost way the cultural information by displaying museum artefacts (Patias et al., 2008). Virtual museums are designed as highly patterned user-constructed experiences based on content, structure, functionality, and interaction. Virtual museums enhance the social virtual value shared or specific to each user. The virtual landscape allows both clear navigation and nonlinear interaction between the site and the audience (Deshpande, Geber, \& Timpson, 2007).

\section{Towards a 'shared authority' on cultural heritage by developing technology}

As social and cultural organisations embedded within society, museums develop the potential of information technology, strengthening the relationship with audiences, and making the museum more accessible and proactive organisation in information-seeking (Bearman \& Gebra, 2008). Museums contribute to the cultural, economic, and social development of society and community by involving users in managing collection and creating value through participatory engagement and digital cultural heritage (Pruulman-Vengerfeldt \& Aljas, 2009). 
Technology helps to democratise knowledge and definition of contents in the cultural heritage field and enables museums to redefine cultural authority adapting to changing society (Bautista, 2014). Museums are strategically embracing the Internet, using social media to create value and develop a loyal relationship with an audience over time (Padilla-Meléndez \& del Águila-Obra, 2013) through websites as brochures and information sources or communication channels that reinforce the strategic link between the website and the physical place, using digital technology to reshape the relationship between the museum and the public (Pallud, 2014).

Technology enables the museum an advocate for knowledge (Freedman, 2000) and supports the educational and cultural role of museums in society (MacDonald \& Alsford, 1991). Technology is leading to decentralisation and sharing of cultural authority on heritage, driving museums to abandon the exclusive role of a key intermediary of knowledge, enabling the museum staff and experts, motivated individuals and communities to produce museum knowledge in a socially defined context (Verboom \& Arora, 2013).

As providers of authentic cultural knowledge museums reconcile their authority on cultural heritage with the need for participation of users in defining cultural contents (Russo, Watkins, Kelly, \& Chan, 2008). Museums are embracing a Web 2.0 mind-set in order to cede authority giving staff and communities permission to experiment and play, then learn from them, encourage internal and external networks (Schweibenz, 2011; Kelly, 2010). Museums are embracing the way for digitisation of cultural heritage materials, fostering participation and encouraging audiences as active participants in cultural heritage (Pruulman-Vengerfeldt \& Aljas, 2009).

While Web 1.0 was mainly focused on information provision and a one-to-many communication model, Web 2.0 facilitates interactive information sharing, collaboration, and user-centred design. Users are at the centre of knowledge and information management and creation. As organisations in transition from Web 1.0 to Web 2.0 technology, museums are moving from consumption-centred to production-centred organisations which strengthen dialogic interaction, distributed information, passion and emotion, collective expertise, participatory communication, collaboration, and sharing of cultural contents. The users are in transition from being merely consumers or a passive audience to becoming co-creators and contributors of cultural products and heritage. Web 2.0 opens up to decentralisation and democratisation of information and knowledge management and sharing information (Bonacini, 2012).

Museums shape knowledge through technology to support the authority derived from the primacy of object collection, by developing two-way communication with users, by fostering trust-based participation with community and individuals potentially (Schweibenz, 1998). Museums are moving from a one-to-many communication in which curatorial expertise is broadcast to the community to two-way communication with visitors engaging in participatory communication using social media for networking and collaboration (Russo, Watkins, Kelly, \& Chan, 2008), developing interactive and collaborative spaces and dialogic communication between the museum and the public (Capriotti \& Kuklinski, 2012).

Museums pay attention to social aspects of technology by promoting new cultural experiences and active participation of users as producers of knowledge and value for a museum as a community (Schweibenz, 2011). Museums are following a service-centred paradigm emphasising the intangible aspects of the museum experience (Alcaraz, Hume, \& Mort, 2009). Web 2.0 is driving museums to become an aggregating centre encouraging voluntary discussion, exchange, active involvement, collaboration, and knowledge sharing (Lòpez, Margapoti, Maragliano, \& Bove, 2012). Thereby, Web 2.0 is a platform for user interaction, exchange of information and thoughts, leading to new and complex knowledge (Shang, Li, Wu, \& Hou, 2011). Web 2.0 based systems offer different 
ways for sharing knowledge and generating collaborative learning (Barak, Orit, Zyia, \& Dory, 2009). New media and technology enable museums to reshape the processes of learning and producing content, providing audience-focused services, encouraging the audiences to interact with a museum as a community (Russo \& Watkins, 2007), by creating an online community, enforcing the social involvement in virtual activities, increasing visits (Mancini \& Carreras, 2010).

Museums use social media to enhance the social experience of visiting a museum allow visitors access to the material without the intervention of curatorial practices (Russo, Watkins, Kelly, \& Chan, 2007) by sharing information between communities of interest, visitors and museum professionals, to create new knowledge, digital cultural content which enables the interpretation of collections from a visitor perspective. By using social media, museums become part of knowledge-sharing networks and lead the audience to be critical learners and creators of digital cultural content promoting user-led innovation (Wilson, 2011), encouraging user participation (Marty, 2011). Museums should implement the four and five levels of social participation Web 2.0 enabling data sharing and flexible use for a better individual experience or providing social tools encouraging the interaction among users as to building trust with visitors able to create and judge (Simon, 2007).

\section{Discussion and conclusions}

Today, museums are changing by moving from being organisations merely designing virtual museums, technology-centred, to becoming organisations that are structuring the user-centred social museum, as a space of innovation and platform for collaboration, a repository of knowledge and information-intensive utility, by engaging people and visitors as active participants in knowledge sharing and creation. Technology helps the museum to focus the attention mainly on objects and collections or to privilege the contribution and expertise of users and audience to enrich knowledge and spread more information.

Museums design virtual museums as a complementary tool or develop the potential of Web 2.0 to design virtual museums as a communicative projection and extent of the traditional museum, opening up to significant participation and contribution of the public and audience. Thereby, different scenarios may emerge.

Museums use technology to develop new forms of the traditional presentation of collection or behave as an information utility. Social museums are opening to interactive and two-way communication or emphasising the contribution of the audience for the definition of contents. They behave as participatory and knowledge-oriented organisations which promote social learning and innovation to contribute to the cultural development of society. As information or knowledge-oriented organisations, museums select different choices using technology by focusing the attention on collection or audience as shown in Figure 1.

\begin{tabular}{|c|c|c|c|}
\hline & Focus on Collections & Focus on Audience & \\
\hline $\begin{array}{r}\text { Information } \\
\text { provision }\end{array}$ & $\begin{array}{l}\text { Virtual-centred } \\
\text { Museum }\end{array}$ & $\begin{array}{c}\text { Information-driven } \\
\text { Museum }\end{array}$ & Services-driven \\
\hline $\begin{array}{r}\text { Developing } \\
\text { Participation }\end{array}$ & $\begin{array}{l}\text { Communication- } \\
\text { enabled } \\
\text { Museum }\end{array}$ & $\begin{array}{c}\text { Social } \\
\text { Museum }\end{array}$ & Processes-oriented \\
\hline
\end{tabular}

Figure 1. From Virtual to Social Museums: a framework of analysis 
Social museums are human-centred and audience-focused organisations that develop processes and encourage user participation, strengthening the potential of ICT and virtual environments, involving the users as co-producers of knowledge in cultural heritage contents.

The main contribution of this study is to explain that museums are using the potential of technology to strengthen the participatory potential of the museum as space and community, and to promote social innovation, becoming an aggregating centre and social-driven organisation which encourages the users to play a proactive role as producers of information and knowledge and to co-produce and co-create social and public value about cultural heritage (Scott, 2010).

There are some implications of this study. As organisations, museums have to redesign both the structure and human resource management policies and processes, strengthening the role of museum professionals in the interaction with users and the audience. Visitors and users are becoming part of the museum as organisation. They contribute to shaping the museum as a community. Technology helps the museum to revisit the identity of a museum and develop continuous human-centred processes, social and technological innovation.

This study is descriptive and exploratory. Future research should investigate how museums within Campania Region are effectively embracing and developing the technology to foster participation, engage visitors to be involved in the interaction with digital images and objects, or follow a traditional presentation of cultural contents that defies the potential of interactive technology available for use and social value promotion.

\section{References}

Addison, A. (2000). Emerging trends in virtual heritage. IEEE Multimedia, 7(2), 22 - 25. https://doi.org/10.1109/93.848421

Alcaraz, C., Hume, M., \& Mort, G. S. (2009). Creating sustainable practice in a museum context: Adopting service-centricity in non-profit museums. Australasian Marketing Journal, 17(4), 219-225. https://doi.org/10.1016/j.ausmj.2009.06.003

Anderson, M. L. (1999). Museums of the future: The impact of technology on museum practices, Daedalus, 128(3), 129-162.

Antinucci, F. (2007). The Virtual Museum. Archeologia e Calcolatori, Supplemento, 1, 7986.

Antinucci, F. (1998). Musei e nuove tecnologie: dov'è il problema? [Museums and the new technology: where is the problem?]. Sistemi intelligenti [Intelligent systems], 10(2), 281-306.

Arnold, D. B., \& Geser, G. (2007). Research agenda for the applications of ICT to cultural heritage. Archeolingua.

Bagdadli, S. (1997). Il museo come azienda. Management e organizzazione al servizio della cultura [The museum as a company. Management and organization at the service of culture]. Etas.

Barak, M., Herscoviz, O., Kaberman, Z., \& Dori, Y. J. (2009). MOSAICA: A web-2.0 based system for the preservation and presentation of cultural heritage. Computers \& Education, 53(3), 841-852.

Bautista, S. S. (2014). Museums in the Digital Age. Changing Meanings of Place, Community, and Culture. AltaMira Press.

Bearman, D., \& Gebra, K. (2008). Transforming Cultural Heritage Institutions through New Media. Museum Management and Curatorship, 23(4), 385-399. https://doi.org/10.1080/09647770802517431 
Bonacini, E. (2012). Il museo partecipativo sul web: forme di partecipazione dell'utente alla produzione culturale e alla creazione di valore culturale [The participatory museum on the Web: forms of user participation in cultural production and the creation of cultural value]. Il capitale culturale. Studies on the Value of Cultural Heritage, 5, 93-125. https://doi.org/10.13138/2039-2362/201

Burton, C., \& Scott, C. (2007). Museums. Challenges for the 21st century. In R. Sandell \& R.R. Janes (Eds.), Museum Management and Marketing (pp. 49-66), Routledge.

Camarero, C., \& Garrido, M. J. (2008). The role of technological and organizational innovation in the relation between market orientation and performance in cultural organizations. European Journal of Innovation Management, 11(3), 413434. https://doi.org/10.1108/14601060810889035

Capriotti, P., \& Kuklinski, H. P. (2012). Assessing dialogic communication through the Internet in Spanish museums. Public Relations Review, 38(4), 619-626. https://doi.org/10.1016/j.pubrev.2012.05005

Carrozzino, M., \& Bergamasco, M. (2010). Beyond virtual museums: Experiencing immersive virtual reality in real museums. Journal of Cultural Heritage, 11, 452 458. https://doi.org/10.1016/j.culher.2010.04.001

Castells, M. (2001). Museums in the information era. Cultural connectors of time and space. ICOM News, 1-4. https://icom.museum/wpcontent/uploads/2018/07/ICOM_ENG_10_2001_small.pdf

Charitos, D., Lepouras, G., Vassilakis, C., Katifori, V., Charissi, A., \& Halatsi, L. (2001). Designing a virtual museum within a museum. In Proceedings of the 2001 conference on Virtual reality, archeology, and cultural heritage, 28(30), 284. https://doi.org/10.1145/584993.585043

Chiu, M. L., Lin,Y. T., Tseng, K. W., \& Chen, C. H. (2000). Museum of Interface. Designing the Virtual Environment. In Proceedings of the Fifth International Conference of CAADRIA 2000, Singapore (pp. 471-480).

Council of Europe (2005, October 27). Council of Europe Framework Convention on the Value of Cultural Heritage for Society. Faro, 27.10.2005.

Davies, S. M., Paton, R., \& O’Sullivan, T. J. (2013). The museum values framework: a framework for understanding organisational culture in museums. Museum Management and Curatorship, 28(4), 345-361. https://doi.org/10.1080/09647775.2013.831247

Delle Nogare, C., \& Murzyn-Kupisz, M. (2021). Do museums foster innovation through engagement with the cultural and creative industries?. Journal of Cultural Economics, https://doi.org/10.1007/s10824-021-09418-3

Denyer, D., \& Tranfield, D. (2006). Using qualitative research synthesis to build an actionable knowledge base. Management Decision, 44(2), 213-227. https://doi.org/10.1108/00251740610650201

Dixon-Woods M., Agarwal, S., Young, B., Jones, D., \& Sutton, A. (2004). Integrative Approaches to Qualitative and Quantitative Evidence. Health Development Agency.

Deshpande, S., Geber, K., \& Timpson, C. (2007). Engaged Dialogism in Virtual Space: An Exploration of Research Strategies for Virtual Museums. In F. Cameron and S. Kenderline (Eds.), Theorizing Digital Cultural Heritage. A Critical Discourse (pp. 261-279). The MIT Press. https://doi.org/10.7551/mitpress/9780262033534.001.0001

d'Harnoncourt, A., DiMaggio, P., Perry, M., \& Wood, J. N. (1991). The Museum and the Public. In Feldstein, M. (Ed.), The Economics of Art Museums (pp. 35-60). University of Chicago Press.

Economou, M. (1998). The evaluation of museum multimedia applications: lessons from research. Museum Management and Curatorship, 17(2), 173-187. https://doi.org/10.1080/09647779800501702

Economou, M., \& Pujol, L. (2008). Educational tool or expensive toy? Evaluating VR evaluation and its relevance for virtual heritage. In Y. Kalay, T. Kvan, \& J. Afflek (Eds.), New Heritage: New Media and Cultural Heritage (pp. 242-260), Routledge-Taylor and Francis Group. 
Freedman, G. (2000). The changing nature of museums. Curator: The Museum Journal, 43(4), 295-306. https://doi.org/10.1111/j.2151-6952.2000.tb00013.x

Gilmore, A., \& Rentschler, R. (2002). Changes in museum management. A custodial or marketing emphasis?. Journal of Management Development, 21(10), 745-760. https://doi.org/10.1108/02621710210448020

Hazan, S. (2007). A crisis of Authority: New Lamps for Old. In F. Cameron, \& S. Kenderline (Eds.), Theorizing Digital Cultural Heritage. A Critical Discourse (pp. 133-147), The MIT Press. https://doi.org/10.7551/mitpress/9780262033534.001.0001

Hein, G.E. (2005). The role of museums in society: Education and social action. Curator: The Museum Journal, 48(4), 357-363.

Holden, J. (2006). Cultural Value and the Crisis of Legitimacy. Why culture need a democratic mandate. Demos.

Hooper-Greenhill, E. (1992). Museums and the Shaping of knowledge. Routledge.

Hooper-Greenhill, E. (1995). Museums and communication: an introductory essay. In Hooper-Greenhill, E. (Ed.), Museum, Media, Message (pp. 1-12). Routledge. https://doi.org/10.4324/9780203456514

Hooper-Greenhill, E. (2007). Museums: learning and culture. In E. Hooper-Greenhill (Ed.), Museum and Education. Purpose, Pedagogy, Performance (pp. 1-14). Routledge. https://doi.org/10.4324/9780203937525

Huvila, I. (2013). How a museum knows? Structures, work roles, and infrastructures of information work. Journal of the American Society for Information Science and Technology, 64(7), 1375-1387. https://doi.org/10.1002/asi.22852

Keene, S. (1996). Becoming digital. Museum Management and Curatorship, 15(3), 299313. https://doi.org/10.1016/S0260-4779(96)00045-3

Kelly, L. (2010). How Web 2.0 is changing the nature of museum work. Curator: The Museum Journal, 53(4), 405-410. https://doi.org/10.1111/j.21516952.2010.00042.x

López, X., Margapoti, I., Maragliano, R., \& Bove, G. (2010). The presence of Web 2.0 tools on museum websites: a comparative study between England, France, Spain, Italy and the USA. Museum Management and Curatorship, 25(2), 235-249. https://doi.org/10.1080/09647771003737356

Loulanski, T. (2006). Revising the Concept for Cultural Heritage: The Argument for a Functional Approach. International Journal of Cultural Property, 13(2), 207-233. https://doi.org/10.1017/S0940739106060085

MacDonald, G. F., \& Alsford, S. (1991). The museum as information utility. Museum Management and Curatorship, 10(3), 305-311.

Mackay, H., \& Gillespie, G. (1992). Extending the social shaping of technology approach: ideology and appropriation. Social Studies of Science, 22(4), 685-716. https://doi.org/10.1177/030631292022004006

Malraux, A. (1965). Le Musée imaginaire 1947. Gallimard.

Mancini, F., \& Carreras, C. (2010). Techno-society at the service of memory institutions: Web 2.0 in museums. Catalan Journal of Communication \& Cultural Studies, 2(1), 59-75. https/doi.org/10.1386/cjcs.2.1.59_1

Marty, P. F. (2011). My lost museum: User expectations and motivations for creating personal digital collections on museum websites. Library \& Information Science Research, 33(3), 211-219. https://doi.org/10.1016/j.lisr.2010.11.003

Marty, P. F. (2007). Museum professionals and the relevance of LIS expertise. Library \& Information Science Research, 29(2), 252-276. https://doi.org/10.1016/j.lisr.2006.10.008

Mulgan, G. (2006). The Process of Social Innovation. Innovations: technology, governance and globalization, 1(2), 145-162.

Murzyn-Kupisz, M., \& Dzialek J. (2013). Cultural heritage in building and enhancing social capital. Journal of Cultural Heritage Management and Sustainable Development, 3(1), 35-54. https://doi.org/10.1108/20441261311317392

Niccolucci, F. (2007). Virtual Museums and Archaeology: An International Perspective. Archeologia e Calcolatori, 1, 15-30. 
Orna, E., \& Pettitt, C. (2010). What is Information in the Museum Context?, In R. Parry (Ed.), Museums in a digital age (pp. 28-38), Routledge.

Ott, M., \& Pozzi, F. (2011). Towards a new era for Cultural Heritage Education: Discussing the role of ICT. Computers in Human Behavior, 27(4), 1365-1371. https://doi.org/10.1016/j.chb.2010.07.031

Padilla-Meléndez, A., \& del Águila-Obra, A. R. (2013). Web and social media usage by museums: Online value creation. International Journal of Information Management, 33(5), 892-898. https://doi.org/10.1016/j.ijinfomgt.2013.07.004

Pallud, J., \& Straub, D. W. (2014). Effective website design for experience-influenced environments: The case of high culture museums. Information \& Management, 51(3), 359-373. https://doi.org/10.1016/j.im.2014.02.010

Patias, P., Chrysantou, Y., Sylaiou, S., Georgiadis, C., Michail, D., \& Stylianidis, S. (2008). The development of an e-museum for contemporary arts. In Conference on Virtual Systems and Multimedia (pp. 20-25).

Pop, I. L., \& Borza, A. (2014). Increasing the Sustainability of Museums through International Strategy. Economia, Management Series, 17(2), 248-264.

Pruulmann-Vengerfeldt, P., \& Aljas, A., (2009). Digital Cultural Heritage - Challenging Museums, Archives and Users. Journal of Ethnology and Folkloristics, 3(1), 109128.

Robles-Ortega, M. D., Feito, F. R., Jiménez, J. J., \& Segura, R. J. (2012). Web technologies applied to virtual heritage: An example of an Iberian Art Museum. Journal of Cultural Heritage, 13(3), 326-331. https://doi.org/10.1016/j.culher.2011.10.001

Roussou, M. (2002). Virtual Heritage: From the Research Lab to the Broad Public. Bar International Series, 1075, 93-100.

Roussou, M. (2008). The components of engagement in virtual heritage environments. In Proceedings of New Heritage: Beyond Verisimilitude - Conference on Cultural Heritage and New Media (pp. 265-283), Hong Kong.

Russo, A., Watkins, J., Kelly, L., \& Chan, S. (2008). Participatory Communication with Social Media. Curator: The Museum Journal, 51(1), 21-31. https://doi.org/10.1111/j.2151-6952.2008.tb00292.x

Russo, A. (2011). Transformations in Cultural Communication: Social Media, Cultural Exchange, and Creative Connections. Curator: The Museum Journal, 54(3), 327346. https://doi.org/10.1111/j.2151-6952.2011.00095.x

Russo, A., \& Watkins, J. (2008). New literacy new audiences: Social media and cultural institutions. Electronic Visualisation and the Arts (EVA 2008), 225-239.

Russo, A., Watkins, J., Kelly, L., \& Chan, S. (2007). Social media and cultural interactive experiences in museums. Nordisk Museology, 1, 19-29.

Russo, A., \& Watkins, J. (2007) Digital Cultural Communication: Audience and Remediation. In F. Cameron and S. Kenderline (Eds.), Theorizing Digital Cultural Heritage. A Critical Discourse (pp. 149-164), The MIT Press. https://doi.org/10.7551/mitpress/9780262033534.001.0001

Schroeder, R. (2008). Defining virtual worlds and virtual environments. Journal for Virtual Worlds Research, 1(1).

Schweibenz, W. (2011). Museum and Web 2.0: Some Thoughts about Authority, Communication, Participation and Trust. In Styliaras G., Koukopoulos D., Lazarinis F. (Eds.), Handbook of Research on Technologies and Cultural Heritage: Application and Environments (pp. 1-15), IGI Global.

Schweibenz, W. (1998). "The Virtual Museum": New Perspectives for Museums to Present Objects and Information Using the Internet as a Knowledge Base and Communication System. In 6. Internationalen Symposiums fùr Informationswissenschaft, Prague, 3-7, November (pp. 185-200).

Scott, C. (2010). Museums, the Public, and Public Value. Journal of Museum Education, 35(1), 33-42. https://doi.org/10.1080/10598650.2010.11510648

Scott, C. (2003). Museums and Impact. Curator: The Museum Journal, 46(3), 293-310. https://doi.org/10.1111/j.2151-6952.2003.tb00096.x

Shahani, L., Economou, M., \& Nikonakou, N. (2008). Museums Curating Online Content Using Web 2.0: Making Cultural Production More Democratic?. In The Annual 
Conference of the International Documentation Committee of the International Council of Museums.

Shang, S. S. C, Li, E. Y., Wu, Y.-L., \& Hou, O. C. L. (2011). Understanding Web 2.0 service models: A knowledge-creating perspective. Information\&Management, 48(4-5), 178-184. https://doi.org/10.1016/j.im.2011.01.005

Silberman, N. (2007). Cultural heritage and the information technologies. In Niccolucci, F. (Ed.), Digital Applications for Tangible Cultural Heritage. Report on the State of the Union Policies, Practices and Developments in Europe (Vol. 2, pp. 95-104), Epoch.

Simon, N. (2007). Discourse in the Blogosphere: What Museums Can Learn from Web 2.0. Museums \& Social Issues, 2(2), 257-274. https://doi.org/10.1179/msi.2007.2.2.257

Simon, N. (2010). The participatory museum, Museum 2.0. Santa Cruz.

Srinivasan, R., Becvar, K. M., Boast, R., \& Enote, J. (2010). Diverse knowledges and contact zones within the digital museum. Science, Technology, \& Human Values, 35(5), 735-768. https://doi.org/10.1177/0162243909357755

Stone, R., \& 0jika, T. (2000). Virtual Heritage: What Next?. In IEEE Multimedia, 7(2), 7374. https://doi.org/10.1109/93.848434

Styliani, S., Fotis, L., Kostas, K., \& Petros, P. (2009). Virtual museums, a survey and some issues for consideration. Journal of Cultural Heritage, 10(4), 520-528. https://doi.org/10.1016/j.culher.2009.03.003

Tang, M. C. (2005). Representational practices in digital museums: A case study of the National Digital Museum Project of Taiwan. The International information \& library review, 37(1), 51-60. https://doi.org/10.1080/10572317.2005.10762665

Tost, L. P., \& Champion, E. M. (2007). A critical examination of presence applied to cultural heritage. In The 10th Annual International Workshop on Presence (pp. 245-256).

Tsichritzis, D., \& Gibbs, S. J. (1991). Virtual Museums and Virtual Realities. ICHIM, 17-25.

Vecco, M. (2010). A definition of cultural heritage: From the tangible to intangible. Journal of Cultural Heritage, 11(3), 321-324. https://doi.org/10.1016/j.cuhler.2010.01.006

Verboom, J., \& Arora, P. (2013). Museum 2.0: A study into the culture of expertise within the museum blogosphere. First Monday. 18

Vergo, P. (1989). The New Museology. Reaktion Book.

Vicente, E, Camarero, C., \& Garrido, M. J. (2012). Insights into Innovation in European Museums. Public Management Review, 14(5), 649-679. https://doi.org/10.1080/14719037.2011.642566

Williams, R., \& Edge, D. (1996). The social shaping of technology. Research Policy, 25(6), 865-899. https://doi.org/10.1016/0048-7333(96)00885-2

Wilson, R. J. (2011). Behind the scenes of the museum website. Museum Management and Curatorship, 26(4), 373-389. https://doi.org/10.1080/09647775.2011.603934

Witcomb, A. (2007). The Materiality of Virtual Technologies: A New Approach to Thinking about the Impact of Multimedia in Museums, in Theorizing Digital Cultural Heritage. In F. Cameron \& S. Kenderline (Eds.), Theorizing Digital Cultural Heritage. A Critical Discourse (pp. 35-48). The MIT Press. https://doi.org/10.7551/mitpress/9780262033534.001.0001

Zbuchea, A., \& Bira, M. (2020). Does Stakeholder Management Contribute to a Museum's Sustainable Development?. Management Dynamics in the Knowledge Society, 8(1), 95-107. https://doi.org/10.2478/mdke-2020-0007

Zollo, L., Rialti, R., Marrucci, A., \& Ciappei, C. (2021). How do museums foster loyalty in tech-savvy visitors? The role of social media and digital experience. Current Issues in Tourism, 1-18. https://doi.org/10.1080/13683500.2021.1896487 
92 | Mauro ROMANELLI

Becoming Social Museums by Being Virtual-Oriented and Technology-Driven Organisations

\section{Author biography}

Mauro Romanelli is Assistant Professor in Organisation and Human Resource Management at Parthenope University of Naples, Department of Business and Economics, Napoli, Italy. His research interests are in organisational change, innovation and sustainability within public sector organisations and public administration, organisation, processes and information and communication technology within parliaments, smart and sustainable cities and communities, museums and cultural heritage, healthcare. The teaching activities include Organisation theory and design; Ethics and Organisational behaviour; Human resource management, He is a member of several Scholars' associations such as EGOS (European Group of Organisational Studies), EURAM (European Academy of Management), ASSIOA (Associazione Italiana di Organizzazione Aziendale), AIS (Association of Information System), ItAIS, ICTO, and BSLab.

(C) 2021 Faculty of Management (SNSPA), Author(s). This is an open-access article licensed under the Creative Commons Attribution-NonCommercial-NoDerivs License (http://creativecommons.org/licenses/by-ncnd/4.0/). 